\title{
Complete Atrioventricular Canal Defect Balanced
}

National Cancer Institute

\section{Source}

National Cancer Institute. Complete Atrioventricular Canal Defect Balanced. NCI

Thesaurus. Code C101030.

Atrioventricular septal defect in which the atrioventricular junction is shared evenly between the left ventricle and right ventricle. 